\title{
Noncoding RNPs of Viral Origin
}

\section{Joan Steitz, Sumit Borah, Demian Cazalla, Victor Fok, Robin Lytle, Rachel Mitton-Fry, Kasandra Riley, and Tasleem Samji}

Department of Molecular Biophysics and Biochemistry, Howard Hughes Medical Institute, Yale University School of Medicine, New Haven, Connecticut 06536-0812

Correspondence: joan.steitz@yale.edu

\section{SUMMARY}

Like their host cells, many viruses produce noncoding (nc)RNAs. These show diversity with respect to time of expression during viral infection, length and structure, protein-binding partners and relative abundance compared with their host-cell counterparts. Viruses, with their limited genomic capacity, presumably evolve or acquire ncRNAs only if they selectively enhance the viral life cycle or assist the virus in combating the host's response to infection. Despite much effort, identifying the functions of viral ncRNAs has been extremely challenging. Recent technical advances and enhanced understanding of host-cell ncRNAs promise accelerated insights into the RNA warfare mounted by this fascinating class of RNPs.

\section{Outline}

1 VA RNAs: Multifunctional manipulators of adenovirus host-cell functions

2 EBERs: Abundant but enigmatic contributors to EBV latency

3 HSURs: Managing host microRNA functions during HVS latency

4 PAN RNA: A nuclear sink during the KSHV lytic cycle?
5 Viral microRNAs: Altering host-cell or fine-tuning viral gene expression?

6 Noncoding RNAs of other flavors

7 Prospects

References

Editors: John F. Atkins, Raymond F. Gesteland, and Thomas R. Cech

Additional Perspectives on RNA Worlds available at www.cshperspectives.org

Copyright (C 2011 Cold Spring Harbor Laboratory Press; all rights reserved; doi: 10.1101/cshperspect.a005165

Cite this article as Cold Spring Harb Perspect Biol 2011;3:a005165 
Viruses are the ultimate parasites, capable of redirecting a cell's gene expression apparatus to their own ends. Takeover can occur during both lytic growth and latency, whereby the virus retreats into the infected cell in a state that is dormant but can be re-activated to replicate in some distant cellular descendant. Some-but not all-viruses encode noncoding (nc) RNAs that become viral ribonucleoprotein (RNP) complexes, usually by assembling with host rather than viral RNA-binding proteins. These polypeptides often are well-characterized components of cellular RNPs but can appear in unexpected subcellular locations or function in novel ways when recruited into a viral RNP. Because RNAs are less immunogenic than proteins, a viral ncRNP has the potential to slip under the radar of the host's immune system. Thus, viral ncRNAs provide unique perspectives into cellular function, illustrating the many devious ways in which host-cell metabolism can be manipulated.

The viruses that harbor the best-characterized ncRNAs have double-stranded DNA genomes, infect vertebrates and belong to the adenovirus, herpesvirus, or polyomavirus classes. The herpesviruses exist in two states-latency, sometimes accompanied by cellular transformation, and lytic infection, which can be induced from the latent state. Assigning functions to cellular ncRNAs is not straightforward (in contrast to mRNAs), and viral ncRNAs present even more challenging problems. Here, we review current insights into the roles of viral ncRNPs (Tables 1 and 2) and how they relate to the viral takeover agenda.

\section{VA RNAs: MULTIFUNCTIONAL MANIPULATORS OF ADENOVIRUS HOST-CELL FUNCTIONS}

Adenoviruses infect a wide range of vertebrate hosts, and more than 50 human serotypes have been identified. $\mathrm{Hu}-$ man adenoviruses cause a variety of infections including respiratory illness, conjunctivitis (pinkeye), gastrointestinal infections, and urinary tract infections. The study of adenovirus has led to many important discoveries, including pre-mRNA splicing. Adenovirus was the first human virus shown to be oncogenic (although it has never been found in human cancers). Compromised adenoviruses are also used as delivery agents for gene therapy.

The adenovirus VA (virus-associated) RNAs are not only the first viral ncRNAs to be identified (Reich et al. 1966) but also the best understood in molecular terms. VAI ( 160 nt) is a structured RNA transcribed by RNA polymerase III (Pol III), which accumulates up to $10^{8}$ copies/ cell in late-stage infection of HeLa cells (about the same level as ribosomes) (Fig. 1A)! VAI RNA is required for high titer viral growth and efficient viral mRNA translation (Thimmappaya et al. 1982). It is localized in the cytoplasm and has long been known to combat the interferon response by formation of a stable RNP with cellular PKR (protein kinase R) (Mathews and Shenk 1991). PKR synthesis is induced by interferon, a cell-signaling molecule produced by the host in response to infection; PKR's kinase activity is turned on by subsequent binding of doublestranded RNA (arising from transcription of the viral genome). Activated PKR phosphorylates translation initiation factor eIF2, leading to inhibition of protein synthesis. However, in adenovirus-infected cells, VAI RNA, with its high abundance and double-stranded upper stem, avidly binds PKR (Fig. 1A) in a way that prevents PKR activation and thus enables the virus to elude this aspect of the cellular antiviral response.

Further research has implicated VAI RNA in manipulating other facets of host-cell function, such as the microRNA (miRNA) and RNA interference (RNAi) pathways. VAI has been shown to competitively inhibit export of miRNA precursors from the nucleus by exportin-5 (Lu and Cullen 2004). Moreover, VAI RNA, as well as the structurally similar VAII RNA (Fig. 1A) encoded by many adenovirus strains, competitively inhibits Dicer activity (see Sharp 2010) (Lu and Cullen 2004; Andersson et al. 2005). Binding of Dicer to the VA RNA terminal stem (Fig. 1A) yields cleavage products that are the size of miRNAs $(\sim 22 \mathrm{nt})$, albeit very inefficiently (Andersson et al. 2005; Aparicio et al. 2006; Sano et al. 2006). But because of the high abundance of the VA transcripts, the majority of RISCs (RNA-induced silencing complexes) in late-stage infected cells become loaded with VA RNA-derived sequences (Xu et al. 2007). No viral or cellular targets have yet been experimentally shown for the putative adenovirus miRNAs, leaving the in vivo relevance of these observations as yet unresolved.

\section{EBERS: ABUNDANT BUT ENIGMATIC CONTRIBUTORS TO EBV LATENCY}

Epstein-Barr virus (EBV), a $\gamma$ herpesvirus, is detected in more than $90 \%$ of the human population and persists in most individuals as a lifelong, asymptomatic infection of B lymphocytes. Unfortunately for some, it is also the causative agent of infectious mononucleosis and is associated with malignancies such as Burkitt's lymphoma and nasopharyngeal carcinoma.

The two most abundant viral transcripts in EBVinfected cells are the EBV-encoded RNAs, EBERs1 and 2 (Lerner et al. 1981a) (Fig. 1B). These ncRNAs are so numerous, at approximately $10^{6}$ copies each per infected B cell, that their presence is used in the clinic as diagnostic for EBV's presence (Gulley and Tang 2008). They are also among the few viral gene products expressed in all types of EBV latency (Kieff and Rickinson 2007). EBER1 (167 nts) and EBER2 (172 nts) are highly conserved among 
Table 1. Viral ncRNAs excluding miRNAs

\begin{tabular}{|c|c|c|c|c|c|c|c|}
\hline $\begin{array}{l}\text { Viral Family } \\
\text { (subgroup) }\end{array}$ & Virus & RNA & Abundance (copies/cell) & Length (nt) & RNA Polymerase & Bound Proteins & References \\
\hline \multirow[t]{2}{*}{ Adenoviridae } & \multirow[t]{2}{*}{ Human Adenovirus } & VAI & $10^{8}$ & $\sim 160$ & III & La, PKR, Dicer, Ago2 & {$[1-5]$} \\
\hline & & VAII & $5 \times 10^{6}$ & $\sim 160$ & III & La, Dicer, Ago2 & {$[1,4,5]$} \\
\hline \multirow{3}{*}{$\begin{array}{l}\text { Herpesviridae } \\
\qquad(\alpha \text { herpesvirus })\end{array}$} & \multirow[t]{3}{*}{ HSV-1 } & LAT & $?$ & $\sim 6300$ & II & $?$ & {$[6]$} \\
\hline & & sRNA1 & $?$ & 65 & $?$ & $?$ & {$[7]$} \\
\hline & & sRNA2 & $?$ & 36 & $?$ & $?$ & [7] \\
\hline $\begin{array}{l}\text { Herpesviridae } \\
\quad(\beta \text { herpesvirus })\end{array}$ & HCMV & $\beta 2.7$ & $?$ & 2700 & II & GRIM-19 & {$[8-10]$} \\
\hline \multirow{8}{*}{$\begin{array}{l}\text { Herpesviridae } \\
\quad(\gamma \text { herpesvirus })\end{array}$} & \multirow[t]{4}{*}{ EBV/HHV4 } & EBER1 & $5 \times 10^{6}$ & 167 & III & $\mathrm{La}, \mathrm{L} 22,(\mathrm{PKR})^{*}$ & {$[11-15]$} \\
\hline & & EBER2 & $5 \times 10^{6}$ & 172 & III & $\mathrm{La}$, nucleolin $^{\dagger},(\mathrm{PKR})^{*}$ & {$[11,12,14]$} \\
\hline & & v-snoRNA1 & $?$ & 65 & $?$ & Fibrillarin, Nop56, Nop58 & {$[16]$} \\
\hline & & $\mathrm{v}$-snoRNA1 ${ }^{24 \mathrm{pp}}$ & $?$ & 24 & $?$ & $?$ & {$[16]$} \\
\hline & \multirow[t]{2}{*}{ HVS } & HSUR1,2,5 & $10^{3}-10^{4}$ & $114-143$ & II & Sm $(H u R, ~ h n R N P ~ D)^{\ddagger}$ & {$[17-19]$} \\
\hline & & HSUR3,4,6,7 & $10^{3}-10^{4}$ & $75-106$ & II & $\mathrm{Sm}$ & {$[18]$} \\
\hline & KSHV/HHV8 & PAN & $5 \times 10^{5}$ & $1060^{\#}$ & II & hnRNP C1; PABPC1 & $\begin{array}{l}{[20,21] \text { Borah et al., }} \\
\text { unpub. }\end{array}$ \\
\hline & MHV68 & tRNA1,2,3,4,5,6,7 & $?$ & $72-84$ & III & $?$ & {$[22]$} \\
\hline Tombusviridae & RCNMV & SR1f & $?$ & 400 & $?$ & $?$ & {$[23]$} \\
\hline Flaviviridae & WNV & sgRNA & $?$ & $300-500$ & $?$ & $?$ & {$[24]$} \\
\hline
\end{tabular}

*In vivo binding has not been shown.

${ }^{\dagger}$ Victor Fok unpublished data.

${ }^{*}$ Shown in vivo only for HSUR1 (Cook et al. 2004).

"This value excludes the poly(A) tail. HSV (herpes simplex virus), HCMV (human cytomegalavirus), EBV (Epstein-Barr virus), HHV (human herpes virus), HVS (Herpesvirus saimiri), KSHV (Kaposi's sarcoma-associated herpesvirus), MHV (murine herpesvirus), RCNMV (Red clover necrotic mosaic virus), WNV (West Nile virus).

1. Lerner et al. 1981b; 2. Mathews and Shenk 1991; 3. Lu and Cullen 2004; 4. Andersson et al. 2005; 5. Aparicio et al. 2006; 6. Stevens et al. 1987; 7. Shen et al. 2009; 8. Greenaway and Wilkinson 1987; 9. Reeves et al. 2007; 10. Spector 1996; 11. Lerner et al. 1981a; 12. Toczyski et al. 1994; 13. Clarke et al. 1990; 14. Sharp et al. 1993; 15. Fok et al. 2006a; 16. Hutzinger et al. 2009; 17. Cook et al. $2004 ; 18$. Lee et al. 1988; 19. Myer et al. 1992; 20. Sun et al. 1996; 21. Conrad 2008; 22. Bowden et al. 1997; 23. Iwakawa et al. 2008; 24. Pijlman et al. 2008. 
J. Steitz et al.

Table 2. Validated viral microRNAs

\begin{tabular}{|c|c|c|c|}
\hline Viral Family (subgroup) & Virus & pre-miRNAs & References \\
\hline \multirow[t]{7}{*}{ Herpesviridae ( $\alpha$ herpesvirus) } & GHV1/ILTV & 7 & {$[1]$} \\
\hline & GHV2/MDV type 1 & 14 & {$[1-7]$} \\
\hline & GHV3/MDV type 2 & 18 & {$[1-7]$} \\
\hline & Meleagrid (turkey) HVT & 17 & {$[1,8]$} \\
\hline & HSV1/HHV1 & $5+2^{*}$ & {$[9-13]$} \\
\hline & HSV2/HHV2 & 3 & {$[14,15]$} \\
\hline & $\mathrm{B}$ virus/macacine $\mathrm{HV} 1$ & 3 & {$[16]$} \\
\hline \multirow[t]{2}{*}{ Herpesviridae ( $\beta$ herpesvirus) } & HCMV/HHV5 & 11 & {$[17-21]$} \\
\hline & MCMV & 12 & {$[22-24]$} \\
\hline \multirow[t]{5}{*}{ Herpesviridae ( $\gamma$ herpesvirus) } & $\mathrm{EBV} / \mathrm{HHV} 4$ & 25 & {$[25-28]$} \\
\hline & rLCV & 35 & {$[26,42,43]$} \\
\hline & MHV-68 & 9 & {$[18]$} \\
\hline & KSHV/HHV8 & 13 & {$[18,26,29,30]$} \\
\hline & $\mathrm{rRV}$ & 7 & {$[31]$} \\
\hline \multirow[t]{5}{*}{ Polyomaviridae } & $\mathrm{BK}$ virus & 1 & {$[32]$} \\
\hline & JC virus & 1 & {$[32]$} \\
\hline & murine polyomavirus & 1 & {$[23]$} \\
\hline & SV40 & 1 & {$[33]$} \\
\hline & merkel cell polyomavirus & 1 & {$[34]$} \\
\hline Adenoviridae & human adenovirus & $1^{*}$ & {$[35-37]$} \\
\hline Retroviridae & HIV1 & 3 & {$[38-40]$} \\
\hline Ascoviridae & HvAV & $1^{*}$ & {$[41]$} \\
\hline
\end{tabular}

Numbers of miRNAs reflect validated precursor miRNAs recorded in miRBASE as of October 2009. GHV (Gallid herpesvirus), ILTV (infectious laryngotracheitis virus), MDV (Marek's Disease virus), HVT (herpesvirus of turkeys), HSV (herpes simplex virus), HHV (human herpes virus), HCMV (human cytomegalovirus), MCMV (murine cytomegalovirus), EBV (Epstein-Barr virus), rLCV (rhesus lymphocryptovirus), MHV-68 (murine herpesvirus 68), KSHV (Kaposi's sarcoma-associated herpesvirus), rRV (rhesus rhadinovirus), SV40 (simian virus 40), HIV1 (human immunodeficiency type virus 1), HvAV (Heliothis virescens ascovirus).

*Indicates no miRBASE record.

1. Waidner et al. 2009; 2. Burnside et al. 2006; 3. Yao et al. 2007; 4. Morgan et al. 2008; 5. Xu et al. 2008; 6. Yao et al. 2008; 7. Burnside et al. 2008; 8. Yao et al. 2009; 9. Cui et al. 2006; 10. Peng et al. 2008; 11. Umbach et al. 2008; 12. Wu et al. 2009; 13. Umbach and Cullen 2009; 14. Tang et al. 2008; 15. Tang et al. 2009; 16. Besecker et al. 2009; 17. Dunn et al. 2005; 18. Pfeffer et al. 2005; 19. Fannin Rider et al. 2008; 20. Grey and Nelson 2008; 21. Dolken et al. 2009; 22. Dolken et al. 2007; 23. Sullivan et al. 2009; 24. Buck et al. 2007; 25. Pfeffer et al. 2004; 26. Cai et al. 2006b; 27. Grundhoff et al. 2006; 28. Zhu et al. 2009; 29. Cai and Cullen 2006; 30. Samols et al. 2005; 31. Schafer et al. 2007; 32. Seo et al. 2008; 33. Sullivan et al. 2005; 34. Seo et al. 2009; 35. Andersson et al. 2005; 36. Aparicio et al. 2006; 37. Sano et al. 2006; 38. Lin and Cullen 2007; 39. Ouellet et al. 2008; 40. Omoto and Fujii 2006; 41. Hussain et al. 2008; 42. Walz et al. 2010; 43. Riley et al. 2010.

the various EBV strains that infect primates (Arrand et al. 1989). They reside in and remain confined to the nucleoplasm, without shuttling between the nucleus and the cytoplasm (Howe and Steitz 1986; Fok et al. 2006b). The EBERs are transcribed by RNA Pol III and thus possess a tract of uridylate residues at their $3^{\prime}$ ends. Although EBERs1 and 2 are not similar in sequence, both show a high degree of secondary structure, with multiple stemloop structures that serve as protein-binding sites (see Fig. 1B). The abundance and conservation of the EBERs strongly argue that they are important for EBV infection and latency. Yet, cells infected with mutant EBV lacking the EBER genes are indistinguishable from those infected with wild-type EBV in their growth rate, gene expression or sensitivity to interferon (Swaminathan et al. 1991; Swaminathan et al. 1992).

The earliest notions about the molecular function of the EBERs were fueled by the finding that EBERs appear to substitute for the VA RNAs in rescuing adenovirus-infected cells from the shutdown of protein synthesis caused by activated PKR (Bhat and Thimmappaya 1983; Bhat and Thimmappaya 1985). In vitro, EBERs can bind to PKR directly and inhibit its activity (Clarke et al. 1990; Sharp et al. 1993). However, the distinct subcellular locations of the EBERs and PKR, in the nucleus (Howe and Steitz 1986; Fok et al. 2006b) and cytoplasm (Takizawa et al. 2000), respectively, as well as other data, raise doubts as to whether the EBERs actually modulate PKR activity in infected cells.

Besides PKR, several other proteins are known to interact and form RNP complexes with the EBERs. The La protein, which assists in the correct folding of RNA Pol III transcripts (Wolin and Cedervall 2002), stably binds the $3^{\prime}$-U tails of both EBERs (Lerner et al. 1981a). But because the cellular abundance of La exceeds even that of EBERs, sequestration of this protein is unlikely to be the sole function of EBERs. 
A

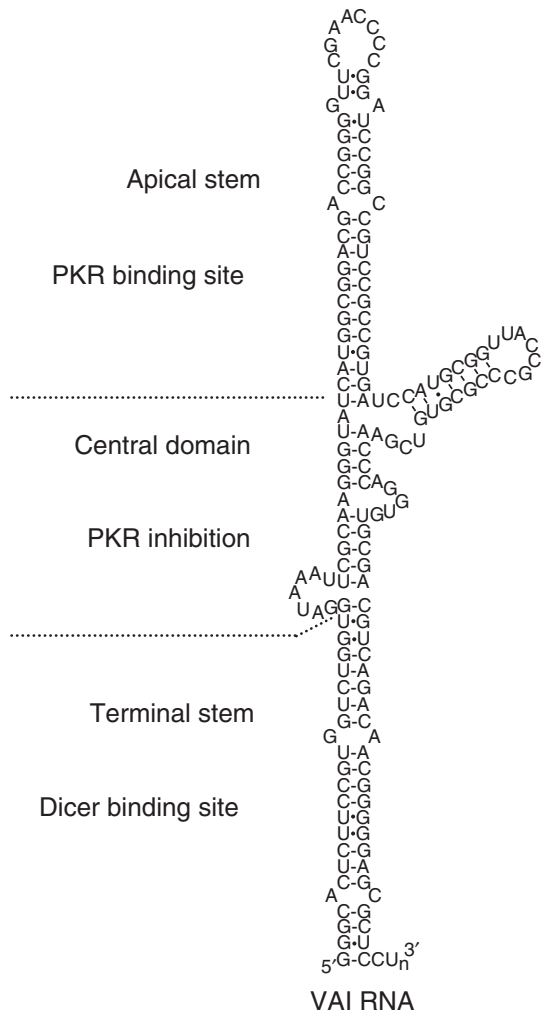

B

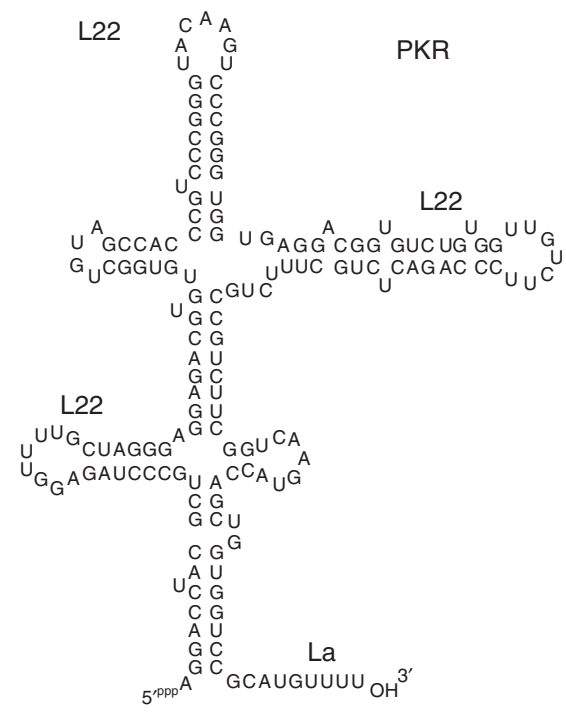

EBER1

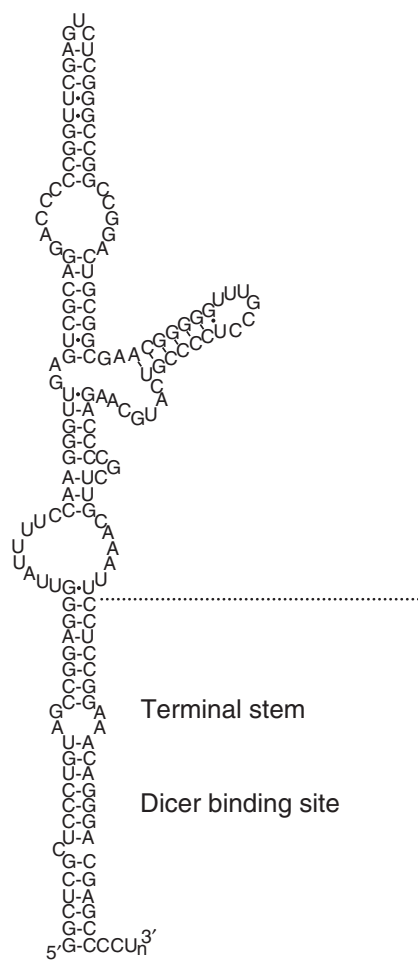

VAII RNA

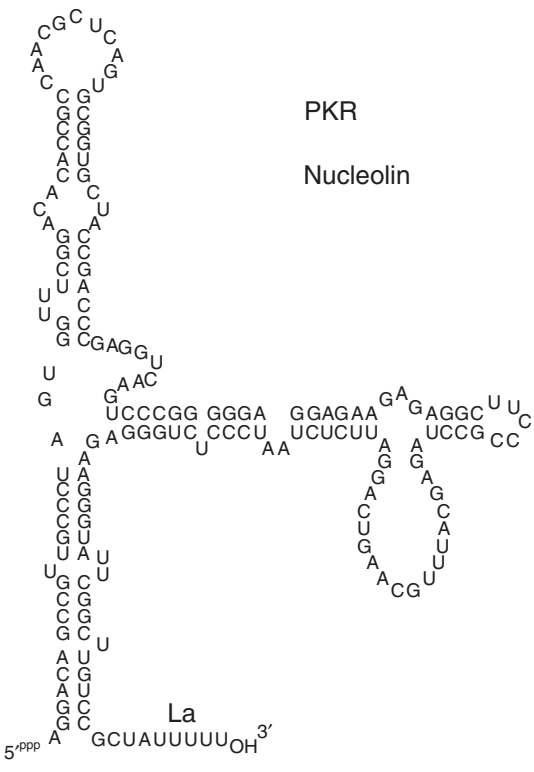

EBER2

Figure 1. (A) VAI and II RNAs. PKR and Dicer interact with nonoverlapping sites on VAI RNA. The apical stem and central domain of VAI RNA bind to and inhibit PKR, respectively, whereas the terminal stems of VAI and VAII RNA interact with Dicer. Cleavage of VAI to produce putative miRNAs has been proposed to leave an upper fragment that remains a potent inhibitor of PKR activity (Wahid et al. 2008). Although there is variation in sequence and length of VA RNAs from different viral strains (RNAs shown are from the much-studied adenovirus type 2 (Ad2)), their general secondary structure is conserved (Ma and Mathews 1996). (B) EBERs1 and 2. EBERs1 and 2 share a high degree of secondary structure and are highly conserved among viruses related to EBV. L22 has been shown to bind to three of EBER1's stem-loops (Fok et al. 2006a), whereas the La protein binds the polyU tract at the $3^{\prime}$ end of the EBERs (Lerner et al. 1981a). The exact sites of binding of PKR to the EBERs or nucleolin to EBER2 have not been determined. 
EBER1 also forms an RNP with ribosomal protein L22; indeed, three molecules of ribosomal protein L22 can bind to EBER1 through three of its stem-loops (Fok et al. 2006a) (Fig. 1B). The binding of L22 to EBER1 causes L22 to appear in the nucleoplasm, as well as its normal location in the nucleolus and cytoplasm (Toczyski et al. 1994). Yet, sequestration of L22 may not have much of an effect on the host cell because mice null for the L22 gene have normal B-cell function (Anderson et al. 2007).

A second binding partner for EBER2 is nucleolin (V Fok, unpubl.), an abundant, multifunctional RNA-binding protein involved in diverse cellular processes (Mongelard and Bouvet 2007). This association is observed only after formaldehyde crosslinking of cells, so it may be weak or transient, but nucleolin binding is specific for EBER2 and-as it is also observed after in vivo UV crosslinking-is a direct RNA-protein contact in EBV-containing cells. In contrast to L22, nucleolin does not appear to become relocalized from nucleoli to the nucleoplasm in the presence of EBERs.

Although a molecular mechanism is lacking, EBERs have been reported to be involved in the up-regulation of a variety of cytokines and growth factors and in the modulation of programmed cell death in EBV-transformed cells. EBERs1 and 2 promote the expression of interleukin-10 (IL-10) in B lymphocytes (Kitagawa et al. 2000), IL-9 in $\mathrm{T}$ cells (Yang et al. 2004), and insulin-like growth factor 1 (IGFI) in epithelial cells (Iwakiri et al. 2003; Iwakiri et al. 2005). In addition, expression of EBER2, but not EBER1, leads to the up-regulation of IL-6 in lymphoblastoid cell lines (Wu et al. 2007). Expression of the EBERs in EBVnegative Akata cells, a Burkitt's lymphoma cell line, restored resistance to spontaneous apoptosis (Komano et al. 1999). Similarly, the EBERs inhibit apoptosis induced by $\alpha$-interferon (Nanbo et al. 2002; Ruf et al. 2005).

The EBERs play a role in oncogenesis as well. Akata cells that spontaneously lose their EBV genome lose their tumorigenic potential (Shimizu et al. 1994). Reintroduction of EBERs alone into these EBV-negative cells restores tumor induction in immunodeficient SCID mice (Ruf et al. 2000). EBERs enhance the immortalization of Akata cells and contribute to their growth rate (Yajima et al. 2005). Also, expressing EBERs1 and 2 in EBV-negative Akata cells increases the size and number of colonies in a soft agar growth assay (Houmani et al. 2009). EBER1's association with L22 is important because EBV-negative Akata cells expressing wild-type EBER2 and an EBER1 in which the three stem-loops responsible for L22 binding had been mutated produced virtually no colonies in the soft agar assay (Houmani et al. 2009). In contrast, EBV from which EBER1 had been deleted was as efficient at transforming cord blood lymphocytes as EBV containing both
EBERs; in this situation, EBER2 alone appeared to be responsible for efficient B-cell growth transformation (Wu et al. 2007). All these tantalizing phenotypes suggest a well-calculated alteration of host gene expression mechanistically linked to the EBERs, but the molecular details remain unclear.

\section{HSURs: MANAGING HOST microRNA FUNCTIONS DURING HVS LATENCY}

Herpesvirus saimiri (HVS) is an oncogenic $\gamma$ herpesvirus that targets the T cells of New World monkeys. Infection with HVS results in either lytic infection or malignant transformation, resulting in aggressive leukemias and lymphomas.

HVS encodes seven ncRNAs, called Herpesvirus saimiri U RNAs (HSURs), that range in size from 75 to 143 nts and are the most abundantly expressed transcripts in latently infected cells (Murthy et al. 1986; Lee et al. 1988; Wassarman et al. 1989; Lee and Steitz 1990; Albrecht and Fleckenstein 1992). Soon after their discovery, HSURs were classified as Sm-class RNAs (Lee et al. 1988) (for more about Sm-class RNAs, see Luhrmann 2010). Besides binding to Sm proteins, HSURs share other structural similarities with cellular Sm snRNPs, including a hypermethylated $5^{\prime}$ cap and a terminal $3^{\prime}$ stem-loop, but they show no significant sequence similarity to any known cellular snRNA. HSURs are well conserved among different HVS subgroups, with HSURs1 and 2 (Fig. 2A) being the most highly conserved and the only snRNAs expressed in the closely related Herpesvirus ateles (Albrecht 2000). This conservation of HSURs1 and 2 suggests that they are important to the virus and do not require the presence of the other HSURs to function.

HSURs1 and 2 contain highly conserved sequences at their $5^{\prime}$ ends that mimic AU-rich elements (AREs) (Lee et al. 1988; Fan et al. 1997). AREs are typically found in the $3^{\prime}$-untranslated region ( $\left.3^{\prime} \mathrm{UTR}\right)$ of cellular mRNAs, where they usually confer instability by inducing rapid and tightly regulated mRNA decay (Garneau et al. 2007). Like their cellular counterparts, the AREs present in HSURs bind ARE-binding proteins (Myer et al. 1992; Cook et al. 2004) and, in the case of HSUR1, regulate its stability (Fan et al. 1997). Nonetheless, the association of HSURs1 and 2 with host ARE-binding proteins does not alter the abundance of host mRNAs containing AREs in HVS-transformed cells (Cook et al. 2004). Instead, upregulation of a handful of proteins that are hallmarks of T-cell activation was observed in cells transformed by the wild-type virus compared with those lacking HSURs1 and 2 (Cook et al. 2005), establishing a phenotype for these viral ncRNAs. 
A

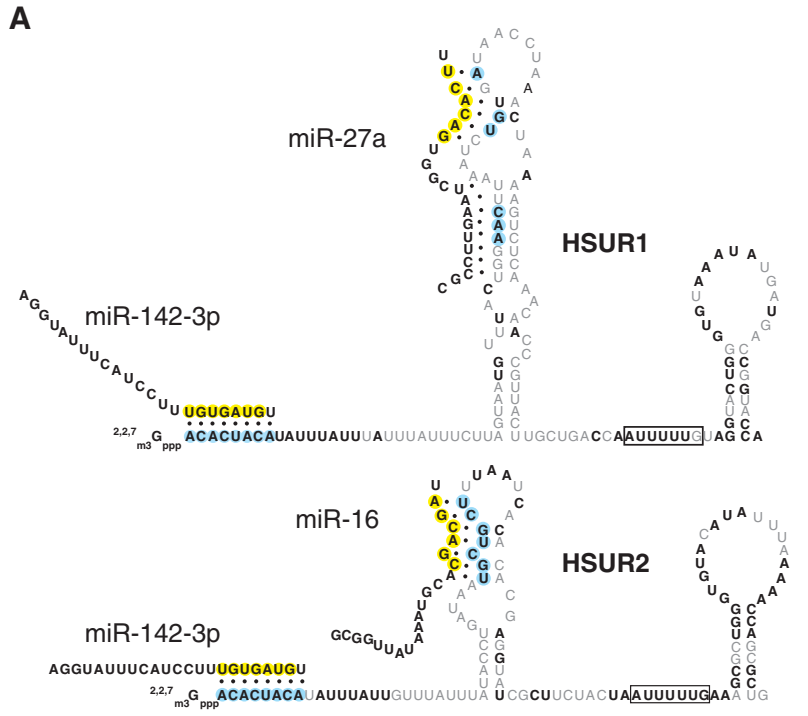

B

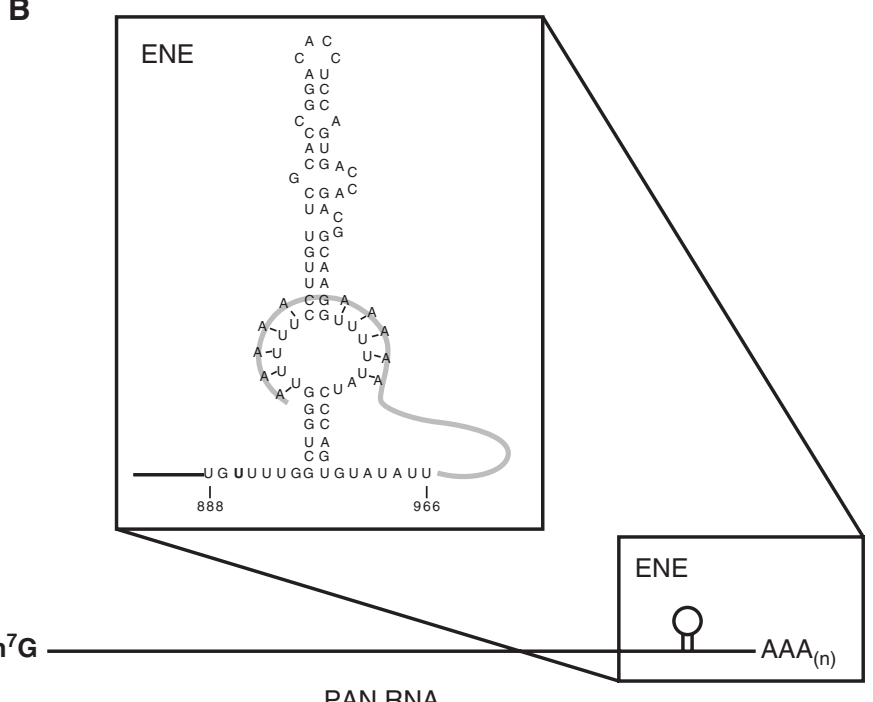

Figure 2. (A) HSURs1 and 2. Predicted base-pairing interactions with miR-16, miR-27a and miR-142-3p are shown. $\mathrm{Sm}$ binding sites are boxed. Gray and black residues in the HSURs indicate nonconserved and perfectly conserved nucleotides, respectively. Residues in blue indicate perfectly conserved nucleotides involved in interactions with miRNAs. Yellow residues in the miRNAs indicate seed sequences. (B) PAN RNA and the ENE. Putative base-pairing interactions between the internal U-rich loop of the ENE and the poly(A) tail are shown.

In addition to their AREs, HSURs1 and 2 possess other perfectly conserved sequences that resemble elements found in the $3^{\prime}$ UTRs of cellular mRNAs, namely binding sites for host miRNAs. (See Sharp 2010 for more on miRNAs.) HSURs1 and 2 both contain two such sites: their $5^{\prime}$-end sequences are complementary to miR-142-3p; downstream of the ARE sequence, HSUR1 contains a binding site for a second miRNA, miR-27, whereas HSUR2 contains a binding site for the miR-16 family of miRNAs (see Fig. 2A). Strikingly, for all three families of miRNAs, complementarity to HSURs involves the critical seed region of the miRNA (Lewis et al. 2005). Although the binding of miR-142-3p and miR-16 to HSURs1 and 2 does not appear to affect the expression of these miRNAs in latently infected cells, the interaction between HSUR1 and miR-27 results in the degradation of mature miR-27 (D Cazalla, unpubl.). Thus, by expressing HSUR1, HVS selectively lowers the abundance of miR-27, consequently altering the expression of genes that are natural targets of miR-27 in transformed T cells. Interestingly, miR-27 targets RUNX1 and FOXO1 (Ben-Ami et al. 2009; Feng et al. 2009; Guttilla and White 2009), transcription factors with roles in tumorigenesis (Blyth et al. 2005; Maiese et al. 2008); their expression is upregulated in virally transformed cells. This is the first example of a virus using the strategy of miRNA down-regulation to control host gene expression and establishes a function for HSUR1.
The observation that HSURs1 and 2 bind miRNAs in latently infected cells opens new avenues in the search for HSUR functions. Why do HSURs mimic cellular mRNA $3^{\prime}$ UTRs in binding miRNAs and ARE-binding proteins? Even though HSURs1 and 2 do not perturb the cellular population of ARE-containing mRNAs (Cook et al. 2004), they may effectively compete with the natural targets of the miR-142-3p and miR-16 families of miRNAs by binding to their seed regions. An alternative possibility is that the $5^{\prime}$ ends of HSURs 1 and 2 provide a platform for deposition of miRNAs and ARE-binding proteins onto specific mRNAs through sequence-specific interactions involving other regions of these HSURs, thereby affecting mRNA translation. Further novel functions seem likely to be identified in studies of this unusual class of viral ncRNAs.

\section{PAN RNA: A NUCLEAR SINK DURING THE KSHV LYTIC CYCLE?}

Kaposi's sarcoma-associated herpesvirus (KSHV) is a $\gamma$ herpesvirus that is the causative agent of several human cancers and lymphoproliferative disorders, including Kaposi's sarcoma (KS), Multicentric Castleman's Disease (MCD) and Primary Effusion Lymphoma (PEL) (Ganem 2006). The virus infects primarily endothelial cells, in the case of KS, and B cells, in the cases of MCD and PEL (Chang et al. 1994; Cesarman et al. 1995; Soulier et al. 
1995; Dupin et al. 1999; Bechtel et al. 2003). Infection with KSHV is particularly serious in patients with compromised or suppressed immune systems, such as AIDS or transplant patients.

KSHV establishes latent infection in the majority of infected cells, and it is unknown which cues stimulate entry of the virus into lytic phase in vivo (Jenner and Boshoff 2002). However, cell cultures harboring the virus can be induced by treatment with sodium butyrate, trichostatin A or valproic acid, which are thought to lead to nonspecific activation of transcription via modification of histones (Countryman et al. 2008). Expression of the viral Orf50 protein is necessary and sufficient to stimulate lytic reactivation, leading it to be referred to as the "master transactivator" switch (Sun et al. 1998).

KSHV expresses an unusual ncRNA called polyadenylated nuclear (PAN) RNA (Sun et al. 1996; Zhong et al. 1996; Zhong and Ganem 1997) on entry into the lytic phase. PAN RNA resembles an mRNA in that it is transcribed by Pol II, is capped at its $5^{\prime}$ end, and ends with a $3^{\prime}$ polyadenylate tail (Fig. 2B). However, unlike mRNAs, PAN RNA is neither spliced nor exported to the cytoplasm. Instead, it remains in the nucleus and accumulates to remarkably high levels, upward of 500,000 copies per lytically infected cell. Ultimately, PAN RNA can account for $80 \%$ of the total polyadenylated RNA in the cell and thus greatly outnumbers all other human or viral mRNAs (Sun et al. 1996).

Why does the virus express so many copies of this one transcript? Moreover, why does PAN RNA look like an mRNA, but not behave like one? Unfortunately, answers to these questions remain elusive, in part because of technical hurdles. A direct approach would be to create a mutant version of the virus incapable of expressing PAN RNA: a PAN "knockout virus." Such a virus could then be compared with wild-type KSHV to discern what contribution PAN RNA makes to the lytic phase. This approach, for instance, was useful for studying the HVS HSURs (see earlier discussion) (Cook et al. 2005). Making a PAN knockout KSHV is problematic because the region of the viral genome from which PAN is transcribed overlaps another viral gene called K7 (Feng et al. 2002; Wang et al. 2002), which functions as an anti-apoptotic factor. Any deletion of the PAN region therefore also disrupts the $\mathrm{K} 7$ gene, complicating the interpretation of a potential PAN RNA knockout phenotype. An alternative is to use antisense approaches to lower the abundance of PAN RNA during the KSHV lytic phase. Although these experiments are not straightforward because of the nuclear localization of PAN RNA, as well as its extremely high levels, new methodologies (Ideue et al. 2009) to overcome such difficulties are extremely promising and may lead to important insights into the functioning of this unusual ncRNA.

Although we still do not know the function of PAN RNA, we have gained some understanding of why it accumulates to such high levels during the KSHV lytic phase. PAN RNA's nuclear abundance can be traced to a highly structured RNA element located just upstream of its $3^{\prime}$ poly(A) tail, called the ENE (Conrad and Steitz 2005) (Fig. 2B). Deletion of the ENE dramatically lowers PAN levels by increasing the decay rate of the RNA (Conrad et al. 2006). Stabilization appears to depend on the ENE's ability to engage PAN's poly(A) tail by base-pairing to an internal loop structure, thereby inhibiting exonucleolytic trimming of the RNA, the first step in decay. One protein that has been shown to physically interact with the ENE sequence is hnRNP C1, although the significance of this interaction is not known (Conrad 2008).

Recently, Glaunsinger and colleagues have reported nuclear accumulation of the cytoplasmic poly(A)-binding protein $\mathrm{C} 1$ (PABPC1) during the lytic phase of KSHV infection (Lee and Glaunsinger 2009). Relocalization appears to be related to the host shutoff effect of the virus, whereby the majority of host mRNAs are selectively degraded while viral mRNAs persist to be translated (Glaunsinger and Ganem 2004). Because PABPC1 has extremely high affinity for poly(A) sequences (Gorlach et al. 1994) and because PAN RNA is an abundant, nuclear polyadenylated transcript, it is likely that PAN RNA serves as a sink for the relocalized PABPC1. How this interaction impacts the host shutoff effect of the virus and the contribution of PAN RNA to the later stages of KSHV lytic growth awaits further investigation. Several other viruses target PABPC1 for nuclear relocalization (rotavirus and herpes simplex virus) or degradation (picornaviruses and caliciviruses), as a component of the shutoff effect for each of these viruses (Dobrikova et al. 2010; Harb et al. 2008; KuyumcuMartinez et al. 2002; Kuyumcu-Martinez et al. 2004a; Kuyumcu-Martinez et al. 2004b).

\section{VIRAL microRNAs: ALTERING HOST-CELL OR FINE-TUNING VIRAL GENE EXPRESSION?}

A novel class of viral ncRNAs was uncovered in 2004 with the discovery of five miRNAs in human B cells latently infected with EBV (Pfeffer et al. 2004). As miRNAs are implicated in regulating expression of the majority of transcripts in mammalian cells (see Sharp 2010), this insight prompted a flurry of investigations that identified miRNAs encoded by a variety of viruses (Table 2 ). Virtually all herpesviruses express relatively large numbers (7-35) of viral miRNAs; indeed, only one herpesvirus tested, varicella zoster virus, lacks detectable miRNA expression during 
latency (Umbach and Cullen 2009). Other viruses with DNA genomes express fewer or no miRNAs. Retroviruses, flaviviruses and other viruses with RNA genomes do not generally encode miRNAs (Pfeffer et al. 2005; Cai et al. 2006a; Lin and Cullen 2007). However, the existence of miRNAs processed by Dicer from the RNA genomes of the human immunodeficiency viruses types 1 (Bennasser et al. 2004; Couturier and Root-Bernstein 2005; Omoto and Fujii 2006; Weinberg and Morris 2006; Klase et al. 2007; Ouellet et al. 2008; Kaul et al. 2009) and 2 (Purzycka and Adamiak 2008) remains controversial (Lin and Cullen 2007). With the advent of high-throughput sequencing technology and its application to different types of cells in various stages of viral infection, our current list of viral miRNAs will likely continue to expand in the near future.

As is the case for cellular miRNAs, understanding the function of viral miRNAs requires identification and validation of their target mRNAs. This has proven to be no small task, as miRNA-mRNA interactions are characterized by imperfect base-pairing in a very loose pattern (Lewis et al. 2005; Grimson et al. 2007; Bartel 2009), varying for different miRNA-mRNA combinations (Didiano and Hobert 2008; Nahvi et al. 2009). Although the list of new viral miRNAs continues to expand, only a few target mRNAs have been validated for an even smaller number of viral miRNAs. These targets can be either host or viral mRNA transcripts. Validation typically includes three steps (see also Sharp 2010): (1) a putative target sequence is cloned into the $3^{\prime} \mathrm{UTR}$ of a reporter construct (e.g., luciferase) and cotransfected into mammalian cells with the miRNA; (2) if repression of reporter activity is observed, then the target must be mutated to abrogate the miRNA-mRNA interaction with predicted loss of repression and ideally, subsequent introduction of compensatory mutations into the miRNA to rescue repression; and (3) miRNA inhibitors (such as antisense) must be shown to increase levels of the putative target protein by relieving miRNA repression. A modest decrease in the abundance of a miRNA-targeted mRNA is often observed in addition to translational downregulation (see Sharp 2010), providing another approach to validation (Grundhoff et al. 2006).

Alteration of as little as a single nucleotide can significantly affect the specificity of a miRNA (Bartel 2004). Whereas a few viral miRNAs are conserved in genomic location, most are not completely conserved in sequence even between very closely related viruses. In notable exception here are the miRNAs of the $\gamma$ herpesviruses EBV and the related monkey virus rLCV (Cai et al. 2006b; Gottwein et al. 2007; Walz et al. 2010; Riley et al. 2010). The majority of EBV and rLCV miRNAs are identical in both sequence and genomic clustering, but each virus intriguingly encodes several sequence-unique miRNAs located within these clusters (Cai et al. 2006b; Walz et al. 2010; Riley et al. 2010). Whether the EBV and rLCV miRNAs are functionally conserved remains to be explored.

In an instance of functional conservation, three different herpesviruses-human cytomegalovirus (HCMV), KSHV, and EBV_-each target a stress-induced human immune ligand (MICB), which is responsible for activating natural killer cell function, with a totally different miRNA (Nachmani et al. 2009). In this way, the three viruses circumvent a key regulator of human immune function. Interestingly, one of these viral miRNAs, KSHV-miR-K12-11, is the only fully validated orthologue of a human miRNA (hsa-miR-155) (Gottwein et al. 2007; Skalsky et al. 2007). Both viral and human miR-155 miRNAs regulate BACH1 , a transcriptional repressor involved in B-cell development (Gottwein et al. 2007). Thus, KSHV uses a miRNA to stall infected B cells at a stage advantageous to the virus.

Although the sequences of their viral miRNAs are not conserved among polyomaviruses, it appears that those expressed by simian virus 40 (SV40) and by the human $\mathrm{BK}$ and JC polyomaviruses target homologous viral transcripts (Sullivan et al. 2005; Seo et al. 2008). This functional conservation is interesting for two additional reasons. First, the miRNAs of these polyomaviruses act as small interfering (si) RNAs, as they are perfectly complementary to and direct mRNA cleavage of their target mRNAs, which are early lytic viral transcripts (Sullivan et al. 2005; Seo et al. 2008). They therefore serve as autoregulators to reduce the levels of the transcripts from which they arise at a later time in infection. Second, these miRNAs are an example of a pair of mature miRNAs processed from the opposite strands of the same precursor miRNA (see Sharp 2010), an efficient use of viral genomic material.

Many targets of viral miRNAs are viral mRNAs, as suggested by bioinformatic studies (Murphy et al. 2008) On cloning the first five viral miRNAs, Tuschl and colleagues hypothesized that the EBV miRNA BART2, whose precursor corresponds to the antisense strand of the EBV DNA polymerase, BALF5, acts as an siRNA to reduce levels of BALF5 (Pfeffer et al. 2004). BART2 down-regulation of BALF5 was later documented in EBV-infected cells, where the BALF5 transcript was shown to undergo cleavage at a specific site directed by BART2 (Barth et al. 2008). Interestingly, the insect virus Heliothis virescens ascovirus (HvAV) also encodes a miRNA that down-regulates its own DNA polymerase, even though the HvAV miRNA does not perfectly base-pair with the polymerase mRNA (Hussain et al. 2008). In some cases, the target viral mRNA is regulated by multiple miRNAs. For example, several of the EBV BART miRNAs from a single genomic cluster (BART1-5p, BART3-5p, BART16, and BART17-5p) work together to down-regulate production of the EBV latency 
membrane protein 1 (LMP1). Of the ten predicted miRNA target sites in the LMP1 3 'UTR for four different EBV miRNAs, two tested as nonfunctional, four weakly regulated LMP1, and four appeared to significantly destabilize the luciferase reporter transcript. Thus, it seems that each miRNA contributes differentially to the down-regulation of LMP1 (Lo et al. 2007).

Oncogenic viruses mount multiple strategies to alter the expression of human tumor suppressor and oncogenes, and miRNAs can now be added to the list of mechanisms they use. For instance, gene expression profiling of human transcripts showed repression of the tumor suppressor THBS1, a regulator of cell adhesion, migration, and angiogenesis, in the presence of KSHV miRNAs (Samols et al. 2007). The EBV miRNA BART5 targets PUMA, an apoptotic host protein that is also controlled at the transcriptional level by p53 (Choy et al. 2008), apparently to ensure survival of latently infected cells.

The expression of viral miRNAs can further be highly regulated during the course of infection, which suits the complex life cycle of viruses. Cloning and quantitative PCR have assessed the range of viral miRNA expression levels under various conditions for EBV, the best studied of the viral miRNA-encoding genomes (Cai et al. 2006b; Xing and Kieff 2007; Cosmopoulos et al. 2009). For example, Daudi cells (EBV-infected Burkitt's lymphoma) express basal levels of BARTs1, 3, 7, 10, BHRF1-1, and BHRF1-2 during latency, but on induction of lytic replication, the levels of all these miRNAs dramatically increase, except for BHRF1-1, which decreases in abundance (Cai et al. 2006b). Two of the EBV miRNAs, BARTs21 and 22, were only recently discovered because they are expressed almost exclusively in some nasopharyngeal carcinomas (Zhu et al. 2009). Because some of the miRNA-containing viruses persist latently in host cells, such as EBV in resting memory B cells, it is conceivable that the viral miRNAs expressed under these conditions up-regulate rather than repress translation of their target mRNAs, as has been observed during the $\mathrm{G}_{0}$ stage of the cell cycle (Vasudevan et al. 2007). Because viral miRNA levels can be regulated by a number of mechanisms, including transcription, processing, and stability, the functional effects of their tight regulation have yet to be fully investigated.

Our increased understanding of the key roles viral miRNAs play in host-virus interactions suggests that viral miRNAs will be suitable targets for antiviral therapy (Kurzynska-Kokorniak et al. 2009). Efficacious therapies may be closer than we might believe. For instance, the polyomaviral miRNAs help maintain evasion of the immune system in infected patients because they down-regulate the expression of viral antigens that trigger an immune response leading to clearance of infected cells (Seo et al.
2008). Thus, agents that down-regulate the polyomaviral miRNAs have significant therapeutic potential.

\section{NONCODING RNAs OF OTHER FLAVORS}

Herpes simplex virus-1 (HSV-1) is a member of the $\alpha$ subgroup of herpesviruses that infects epithelial and neuronal cells. HSV-1 generally establishes latent infection, but it enters the lytic stage under stress conditions. It encodes an abundant $6.3 \mathrm{~kb}$ latent transcript called latency-associated transcript (LAT) (Bloom 2004; Stevens et al. 1987). Although LAT is highly unstable, its $\sim 2 \mathrm{~kb}$ intron accumulates to extremely high levels (Farrell et al. 1991; Kang et al. 2006). The function of LAT remained enigmatic for years, but it has recently been shown to be a miRNA precursor transcript (Umbach et al. 2008; Umbach and Cullen 2009 ). Recent data suggest that the first $1.5 \mathrm{~kb}$ of LAT also give rise to two other small ncRNAs: sRNA1 (65 nt) and sRNA2 (36 nt). These sRNAs co-operate in inhibiting the apoptosis of infected neuronal cells. Furthermore, transfection of rabbit skin cells with the sRNAs prevented viral production. Specifically, sRNA2 inhibits the translation of infected cell protein 4 (ICP4), which is important for the activation and repression of viral transcription during infection (Smith et al. 1993), as ICP4 mRNA levels are not altered. The exact mechanism is unknown (Shen et al. 2009). These two functions imply that the sRNAs are required to prevent reactivation of latent HSV-1 (Shen et al. 2009).

$\mathrm{HCMV}$, a $\beta$ herpesvirus, is the most frequent congenital viral infection in humans. Approximately $5 \%-10 \%$ of infected infants have symptomatic disease associated with serious physical and mental birth defects and mortality (Dollard et al. 2007); in immunocompromised HIV patients or immunosuppressed transplant patients, HCMV can lead to mental retardation, intellectual impairment and deafness (Revello and Gerna 2002). During the early stages of infection, two major unspliced transcripts, which are $1.2 \mathrm{~kb}$ and $2.7 \mathrm{~kb}$ long, are expressed at very high levels (Spector 1996; Greenaway and Wilkinson 1987). Recently, the $2.7 \mathrm{~kb}$ ncRNA has been found to interact with the GRIM-19 (genes associated with retinoid/interferoninduced mortality-19) protein, targeting it to complex I of the electron transport chain in the inner mitochondrial membrane. This interaction is important for maintaining the electrochemical gradient across mitochondrial membranes and thus aids in the production of sufficient ATP to keep the cell alive during infection (Reeves et al. 2007).

EBV, as discussed earlier, encodes both the EBERs and multiple miRNAs in latently infected B cells. By using a method called subtractive hybridization of RNA transcripts (SHORT), Huttenhofer's group identified a number of ncRNAs that are not miRNAs (Mrazek et al. 2007). One 
of these is $65 \mathrm{nt}$ long and contains sequence motifs that assign it to the family of C/D box small nucleolar RNAs; v-snoRNA1 accordingly binds three canonical snoRNA proteins: fibrillarin, Nop56, and Nop58. It does not appear to have any known rRNA or snRNA target and is thus categorized as one of many "orphan snoRNAs." V-snoRNA1 potentially also acts as a miRNA precursor as it is further processed to a $24-n t$ RNA called v-snoRNA1 ${ }^{24 p p}$. This miRNA appears to target cleavage of the $3^{\prime}$ UTR of the viral BALF5 mRNA, which encodes the viral DNA polymerase (Hutzinger et al. 2009), not far from the site where cleavage by EBV-encoded mir-BART2 occurs (see previous). Several cases in which snoRNAs efficiently generate miRNAs have recently been reported (Ender et al. 2008; Scott et al. 2009; Taft et al. 2009).

Murine herpesvirus 68 (MHV-68) belongs to the $\gamma$ subgroup of herpesviruses and has been shown to encode 8 novel tRNA-like genes interspersed with ORFs 1-3. Like tRNAs, these possess Pol III promoter elements and are predicted to assume a tRNA-like cloverleaf secondary structure. Only MHV-68 tRNA7 contains a short tRNAtype intron. These transcripts are expressed at very high levels during both latent and lytic infection. They are processed into mature tRNAs with posttranscriptional addition of 3' CCA termini, but they are not aminoacylated. Their function is unknown (Bowden et al. 1997).

The Red clover necrotic mosaic virus (RCNMV), which is a positive strand RNA virus that infects plants, encodes a $0.4 \mathrm{~kb}$ ncRNA that is packaged into virions, called SR1f. Two RNAs make up the RCNMV genome, RNA1 and RNA2. SR1f is generated from the $3^{\prime}$ UTR of RNA1 and was found to contain a 58-nt sequence (Seq1f58) that protects SR1f from $5^{\prime} \rightarrow 3^{\prime}$ decay. SR 1f appears to inhibit the production of negative-strand RCNMV genomic RNAs via the repression of viral replicase protein production (Iwakawa et al. 2008).

Another ncRNA is found in some members of the Flavivirus family, in particular West Nile virus. Flaviviruses are positive strand RNA viruses that produce a highly structured subgenomic RNA (sgRNA) that is $0.3-0.5 \mathrm{~kb}$ long and is derived from incomplete degradation of the $3^{\prime} \mathrm{UTR}$. The production of sgRNA plays a role in viral replication as well as determining viral pathogenicity as mice infected with the wild-type virus experience severe symptoms, whereas those infected with a mutant virus that does not express the ncRNA show no signs of infection (Pijlman et al. 2008).

\section{PROSPECTS}

The roster of viral-encoded ncRNAs has multiplied in recent years, reflecting the variety of distinct classes of
ncRNAs produced by cellular genomes. Counterparts of snRNAs, snoRNAs, miRNAs, tRNAs, other RNA pol IIItranscribed regulatory RNAs, and large ncRNAs synthesized by RNA pol II are now included in the viral armamentarium. This dazzling diversity is even apparent in the relatively few mechanisms already elucidated whereby viral ncRNAs manipulate gene expression in their host cells. These include sequestering host RNA-binding proteins away from their normal cellular roles and evolving a ncRNA to regulate the activity of a cellular ncRNA.

But many challenges remain, as the functional mechanisms of some viral ncRNAs have remained enigmatic for decades (see Table 1). Clearly, every step of gene expression is a potential target for regulation by a viral ncRNA. Further surprises will undoubtedly emerge as we continue to investigate the molecular basis of the RNA warfare mounted by viruses against their cellular hosts.

\section{ACKNOWLEDGMENTS}

We thank all members of the Steitz lab for stimulating discussions. This work was supported by National Institutes of Health grant CA16038. J.A.S. is an investigator of the Howard Hughes Medical Institute. S.B. was funded by an Anna Fuller Predoctoral Fellowship; R.M-F. by a Postdoctoral Fellowship from the Jane Coffin Childs Fund; and K.R. by an American Cancer Society, New England Chapter-Beatrice Cuneo Postdoctoral Fellowship.

\section{REFERENCES}

Albrecht JC. 2000. Primary structure of the Herpesvirus ateles genome. J Virol 74: 1033-1037.

Albrecht JC, Fleckenstein B. 1992. Nucleotide sequence of HSUR 6 and HSUR 7, two small RNAs of herpesvirus saimiri. Nucleic Acids Res 20: 1810 .

Anderson SJ, Lauritsen JP, Hartman MG, Foushee AM, Lefebvre JM, Shinton SA, Gerhardt B, Hardy RR, Oravecz T, Wiest DL. 2007. Ablation of ribosomal protein L22 selectively impairs $\alpha \beta$ T cell development by activation of a p53-dependent checkpoint. Immunity 26: $759-772$.

Andersson MG, Haasnoot PCJ, Xu N, Berenjian S, Berkhout B, Akusjärvi G. 2005. Suppression of RNA interference by adenovirus virusassociated RNA. J Virol 79: 9556-9565.

Aparicio O, Razquin N, Zaratiegui M, Narvaiza I, Fortes P. 2006. Adenovirus virus-associated RNA is processed to functional interfering RNAs involved in virus production. J Virol 80: 1376-1384.

Arrand JR, Young LS, Tugwood JD. 1989. Two families of sequences in the small RNA-encoding region of Epstein-Barr virus (EBV) correlate with EBV types A and B. J Virol 63: 983-986.

Bartel DP. 2004. MicroRNAs: Genomics, biogenesis, mechanism, and function. Cell 116: 281-297.

Bartel DP. 2009. MicroRNAs: Target recognition and regulatory functions. Cell 136: 215-233.

Barth S, Pfuhl T, Mamiani A, Ehses C, Roemer K, Kremmer E, Jaker C, Hock J, Meister G, Grasser FA. 2008. Epstein-Barr virus-encoded microRNA miR-BART2 down-regulates the viral DNA polymerase BALF5. Nucleic Acids Res 36: 666-675. 
Bechtel JT, Liang Y, Hvidding J, Ganem D. 2003. Host range of Kaposi's sarcoma-associated herpesvirus in cultured cells. J Virol 77: 6474-6481.

Ben-Ami O, Pencovich N, Lotem J, Levanon D, Groner Y. 2009. A regulatory interplay between miR-27a and Runx1 during megakaryopoiesis. Proc Natl Acad Sci 106: 238-243.

Bennasser Y, Le SY, Yeung ML, Jeang KT. 2004. HIV-1 encoded candidate micro-RNAs and their cellular targets. Retrovirology 1: 43.

Besecker MI, Harden ME, Li G, Wang XJ, Griffiths A. 2009. Discovery of herpes B virus-encoded microRNAs. J Virol 83: 3413-3416.

Bhat RA, Thimmappaya B. 1983. Two small RNAs encoded by EpsteinBarr virus can functionally substitute for the virus-associated RNAs in the lytic growth of adenovirus 5. Proc Natl Acad Sci 80: 4789-4793.

Bhat RA, Thimmappaya B. 1985. Construction and analysis of additional adenovirus substitution mutants confirm the complementation of VAI RNA function by two small RNAs encoded by Epstein-Barr virus. J Virol 56: 750-756.

Bloom DC. 2004. HSV LAT and neuronal survival. Int Rev Immunol 23: 187-198.

Blyth K, Cameron ER, Neil JC. 2005. The RUNX genes: Gain or loss of function in cancer. Nat Rev Cancer 5: 376-387.

Bowden RJ, Simas JP, Davis AJ, Efstathiou S. 1997. Murine $\gamma$ herpesvirus 68 encodes tRNA-like sequences which are expressed during latency. J Gen Virol 78: 1675-1687.

Buck AH, Santoyo-Lopez J, Robertson KA, Kumar DS, Reczko M, Ghazal P. 2007. Discrete clusters of virus-encoded microRNAs are associated with complementary strands of the genome and the 7.2-kilobase stable intron in murine cytomegalovirus. J Virol 81: 13761-13770.

Burnside J, Bernberg E, Anderson A, Lu C, Meyers BC, Green PJ, Jain N, Isaacs G, Morgan RW. 2006. Marek's disease virus encodes MicroRNAs that map to meq and the latency-associated transcript. J Virol 80: $8778-8786$.

Burnside J, Ouyang M, Anderson A, Bernberg E, Lu C, Meyers BC, Green PJ, Markis M, Isaacs G, Huang E, et al. 2008. Deep sequencing of chicken microRNAs. BMC Genomics 9: 185.

Cai X, Cullen BR. 2006. Transcriptional origin of Kaposi's sarcomaassociated herpesvirus microRNAs. J Virol 80: 2234-2242.

Cai X, Li G, Laimins LA, Cullen BR. 2006a. Human papillomavirus genotype 31 does not express detectable microRNA levels during latent or productive virus replication. J Virol 80: 10890-10893.

Cai X, Schafer A, Lu S, Bilello JP, Desrosiers RC, Edwards R, Raab-Traub N, Cullen BR. 2006b. Epstein-Barr virus microRNAs are evolutionarily conserved and differentially expressed. PLoS Pathog 2: e23.

Cesarman E, Chang Y, Moore PS, Said JW, Knowles DM. 1995. Kaposi's sarcoma-associated herpesvirus-like DNA sequences in AIDS-related body-cavity-based lymphomas. N Engl J Med 332: 1186-1191.

Chang Y, Cesarman E, Pessin MS, Lee F, Culpepper J, Knowles DM, Moore PS. 1994. Identification of herpesvirus-like DNA sequences in AIDS-associated Kaposi's sarcoma. Science 266: 1865-1869.

Chang K, Elledge SJ, Hannon GJ. 2006. Lessons from Nature: microRNAbased shRNA libraries. Nat Methods 3: 707-714.

Choy EY, Siu KL, Kok KH, Lung RW, Tsang CM, To KF, Kwong DL, Tsao SW, Jin DY. 2008. An Epstein-Barr virus-encoded microRNA targets PUMA to promote host cell survival. J Exp Med 205: 2551-2560.

Clarke PA, Sharp NA, Clemens MJ. 1990. Translational control by the Epstein-Barr virus small RNA EBER-1. Reversal of the doublestranded RNA-induced inhibition of protein synthesis in reticulocyte lysates. Eur J Biochem 193: 635-641.

Conrad NK. 2008. Chapter 15. Co-immunoprecipitation techniques for assessing RNA-protein interactions in vivo. Methods Enzymol 449: 317-342.

Conrad NK, Steitz JA. 2005. A Kaposi's sarcoma virus RNA element that increases the nuclear abundance of intronless transcripts. EMBO J 24: $1831-1841$.

Conrad NK, Mili S, Marshall EL, Shu MD, Steitz JA. 2006. Identification of a rapid mammalian deadenylation-dependent decay pathway and its inhibition by a viral RNA element. Mol Cell 24: 943-953.
Cook HL, Mischo HE, Steitz JA. 2004. The Herpesvirus saimiri small nuclear RNAs recruit AU-rich element-binding proteins but do not alter host AU-rich element-containing mRNA levels in virally transformed T cells. Mol Cell Biol 24: 4522-4533.

Cook HL, Lytle JR, Mischo HE, Li MJ, Rossi JJ, Silva DP, Desrosiers RC, Steitz JA. 2005. Small nuclear RNAs encoded by Herpesvirus saimiri upregulate the expression of genes linked to $\mathrm{T}$ cell activation in virally transformed T cells. Curr Biol 15: 974-979.

Cosmopoulos K, Pegtel M, Hawkins J, Moffett H, Novina C, Middeldorp J, Thorley-Lawson DA. 2009. Comprehensive profiling of EBV microRNAs in nasopharyngeal carcinoma. J Virol 83: 2357-2367.

Countryman JK, Gradoville L, Miller G. 2008. Histone hyperacetylation occurs on promoters of lytic cycle regulatory genes in Epstein-Barr virus-infected cell lines which are refractory to disruption of latency by histone deacetylase inhibitors. J Virol 82: 4706-4719.

Couturier JP, Root-Bernstein RS. 2005. HIV may produce inhibitory microRNAs (miRNAs) that block production of CD28, CD4 and some interleukins. J Theor Biol 235: 169-184.

Cui C, Griffiths A, Li G, Silva LM, Kramer MF, Gaasterland T, Wang XJ, Coen DM. 2006. Prediction and identification of herpes simplex virus 1-encoded microRNAs. J Virol 80: 5499-5508.

Didiano D, Hobert O. 2008. Molecular architecture of a miRNA-regulated 3' UTR. RNA 14: 1297-1317.

Dobrikova E, Shveygert M, Walters R, Gromeier M. 2010. Herpes simplex virus proteins ICP27 and UL47 associate with polyadenylate-binding protein and control its sub-cellular distribution. J Virol 84: 270-279.

Dolken L, Pfeffer S, Koszinowski UH. 2009. Cytomegalovirus microRNAs. Virus Genes 38: 355-364.

Dolken L, Perot J, Cognat V, Alioua A, John M, Soutschek J, Ruzsics Z, Koszinowski U, Voinnet O, Pfeffer S. 2007. Mouse cytomegalovirus microRNAs dominate the cellular small RNA profile during lytic infection and show features of posttranscriptional regulation. J Virol 81: $13771-13782$.

Dollard SC, Grosse SD, Ross DS. 2007. New estimates of the prevalence of neurological and sensory sequelae and mortality associated with congenital cytomegalovirus infection. Rev Med Virol 17: 355-363.

Dunn EF, Hammell CM, Hodge CA, Cole CN. 2005. Yeast poly(A)binding protein, Pab1, and PAN, a poly (A) nuclease complex recruited by Pab1, connect mRNA biogenesis to export. Genes Dev 19: 90-103.

Dupin N, Fisher C, Kellam P, Ariad S, Tulliez M, Franck N, van Marck E, Salmon D, Gorin I, Escande JP, et al. 1999. Distribution of human herpesvirus-8 latently infected cells in Kaposi's sarcoma, multicentric Castleman's disease, and primary effusion lymphoma. Proc Natl Acad Sci 96: 4546-4551.

Ender C, Krek A, Friedlander MR, Beitzinger M, Weinmann L, Chen W, Pfeffer S, Rajewsky N, Meister G. 2008. A human snoRNA with microRNA-like functions. Mol Cell 32: 519-528.

Fan XC, Myer VE, Steitz JA. 1997. AU-rich elements target small nuclear RNAs as well as mRNAs for rapid degradation. Genes Dev 11: 2557-2568.

Fannin Rider PJ, Dunn W, Yang E, Liu F. 2008. Human cytomegalovirus microRNAs. Curr Top Microbiol Immunol 325: 21-39.

Farrell MJ, Dobson AT, Feldman LT. 1991. Herpes simplex virus latency-associated transcript is a stable intron. Proc Natl Acad Sci 88: 790-794.

Feng J, Iwama A, Satake M, Kohu K. 2009. MicroRNA-27 enhances differentiation of myeloblasts into granulocytes by post-transcriptionally downregulating Runx1. Br J Haematol 145: 412-423.

Feng P, Park J, Lee BS, Lee SH, Bram RJ, Jung JU. 2002. Kaposi's sarcoma-associated herpesvirus mitochondrial K7 protein targets a cellular calcium-modulating cyclophilin ligand to modulate intracellular calcium concentration and inhibit apoptosis. J Virol 76: 11491-11504.

Fok V, Friend K, Steitz JA. 2006b. Epstein-Barr virus noncoding RNAs are confined to the nucleus, whereas their partner, the human La protein, undergoes nucleocytoplasmic shuttling. J Cell Biol 173: 319-325. 
Fok V, Mitton-Fry RM, Grech A, Steitz JA. 2006a. Multiple domains of EBER 1, an Epstein-Barr virus non-coding RNA, recruit human ribosomal protein L22. RNA 12: 872-882.

Ganem D. 2006. KSHV infection and the pathogenesis of Kaposi's sarcoma. Annu Rev Pathol 1: 273-296.

Garneau NL, Wilusz J, Wilusz CJ. 2007. The highways and byways of mRNA decay. Nat Rev Mol Cell Biol 8: 113-126.

Glaunsinger B, Ganem D. 2004. Lytic KSHV infection inhibits host gene expression by accelerating global mRNA turnover. Mol Cell 13: $713-723$.

Gorlach M, Burd CG, Dreyfuss G. 1994. The mRNA poly(A)-binding protein: Localization, abundance, and RNA-binding specificity. Exp Cell Res 211: 400-407.

Gottwein E, Mukherjee N, Sachse C, Frenzel C, Majoros WH, Chi JT, Braich R, Manoharan M, Soutschek J, Ohler U, et al. 2007. A viral microRNA functions as an orthologue of cellular miR-155. Nature 450: 1096-1099.

Greenaway PJ, Wilkinson GW. 1987. Nucleotide sequence of the most abundantly transcribed early gene of human cytomegalovirus strain AD169. Virus Res 7: 17-31.

Grey F, Nelson J. 2008. Identification and function of human cytomegalovirus microRNAs. J Clin Virol 41: 186-191.

Grimson A, Farh KK, Johnston WK, Garrett-Engele P, Lim LP, Bartel DP. 2007. MicroRNA targeting specificity in mammals: determinants beyond seed pairing. Mol Cell 27: 91-105.

Grundhoff A, Sullivan CS, Ganem D. 2006. A combined computational and microarray-based approach identifies novel microRNAs encoded by human $\gamma$-herpesviruses. RNA 12: 733-750.

Gulley ML, Tang W. 2008. Laboratory assays for Epstein-Barr virusrelated disease. J Mol Diagn 10: 279-292.

Guttilla IK, White BA. 2009. Coordinate Regulation of FOXO1 by miR-27a, miR-96, and miR-182 in Breast Cancer Cells. J Biol Chem 284: 23204-23216.

Harb M, Becker MM, Vitour D, Baron CH, Vende P, Brown SC, Bolte S, Arold ST, Poncet D. 2008. Nuclear localization of cytoplasmic poly(A)-binding protein upon rotavirus infection involves the interaction of NSP3 with eIF4G and RoXaN. J Virol 82: 11283-11293.

Houmani JL, Davis CI, Ruf IK. 2009. Growth promoting properties of Epstein-Barr virus EBER-1 RNA correlate with ribosomal protein L22 binding. J Virol 83: 9844-9853.

Howe JG, Steitz JA. 1986. Localization of Epstein-Barr virus-encoded small RNAs by in situ hybridization. Proc Natl Acad Sci 83: 9006-9010.

Hussain M, Taft RJ, Asgari S. 2008. An insect virus-encoded microRNA regulates viral replication. J Virol 82: 9164-9170.

Hutzinger R, Feederle R, Mrazek J, Schiefermeier N, Balwierz PJ, Zavolan M, Polacek N, Delecluse HJ, Huttenhofer A. 2009. Expression and processing of a small nucleolar RNA from the Epstein-Barr virus genome. PLoS Pathog 5: e1000547.

Ideue T, Hino K, Kitao S, Yokoi T, Hirose T. 2009. Efficient oligonucleotide-mediated degradation of nuclear noncoding RNAs in mammalian cultured cells. RNA 15: 1578-1587.

Iwakawa HO, Mizumoto H, Nagano H, Imoto Y, Takigawa K, Sarawaneeyaruk S, Kaido M, Mise K, Okuno T. 2008. A viral noncoding RNA generated by cis-element-mediated protection against 5 ' $\rightarrow 3^{\prime}$ RNA decay represses both cap-independent and cap-dependent translation. J Virol 82: 10162-10174.

Iwakiri D, Eizuru Y, Tokunaga M, Takada K. 2003. Autocrine growth of Epstein-Barr virus-positive gastric carcinoma cells mediated by an Epstein-Barr virus-encoded small RNA. Cancer Res 63: 7062-7067.

Iwakiri D, Sheen TS, Chen JY, Huang DP, Takada K. 2005. Epstein-Barr virus-encoded small RNA induces insulin-like growth factor 1 and supports growth of nasopharyngeal carcinoma-derived cell lines. Oncogene 24: 1767-1773.

Jenner RG, Boshoff C. 2002. The molecular pathology of Kaposi's sarcoma-associated herpesvirus. Biochim Biophys Acta 1602: 1-22.

Kang W, Mukerjee R, Gartner JJ, Hatzigeorgiou AG, Sandri-Goldin RM, Fraser NW. 2006. Characterization of a spliced exon product of herpes simplex type-1 latency-associated transcript in productively infected cells. Virology 356: 106-114.

Kaul D, Ahlawat A, Gupta SD. 2009. HIV-1 genome-encoded hiv1-mir-H1 impairs cellular responses to infection. Mol Cell Biochem 323: $143-148$.

Kieff E, Rickinson AB. 2007. Epstein-Barr virus and its replication. in Fields Virology (ed. Knipe D.M., Howley P.M.), pp. 2603-2654. Lippincott Williams \& Wilkins, Philadelphia.

Kitagawa N, Goto M, Kurozumi K, Maruo S, Fukayama M, Naoe T, Yasukawa M, Hino K, Suzuki T, Todo S, et al. 2000. Epstein-Barr virus-encoded poly(A)(-) RNA supports Burkitt's lymphoma growth through interleukin-10 induction. EMBO J 19: 6742-6750.

Klase Z, Kale P, Winograd R, Gupta MV, Heydarian M, Berro R, McCaffrey T, Kashanchi F. 2007. HIV-1 TAR element is processed by Dicer to yield a viral micro-RNA involved in chromatin remodeling of the viral LTR. BMC Mol Biol 8: 63.

Komano J, Maruo S, Kurozumi K, Oda T, Takada K. 1999. Oncogenic role of Epstein-Barr virus-encoded RNAs in Burkitt's lymphoma cell line Akata. J Virol 73: 9827-9831.

Kurzynska-Kokorniak A, Jackowiak P, Figlerowicz M. 2009. Human- and virus-encoded microRNAs as potential targets of antiviral therapy. Mini Rev Med Chem 9: 927-937.

Kuyumcu-Martinez M, Belliot G, Sosnovtsev SV, Chang KO, Green KY, Lloyd RE. 2004a. Calicivirus 3C-like proteinase inhibits cellular translation by cleavage of poly(A)-binding protein. J Virol 78: 8172-8182.

Kuyumcu-Martinez NM, Joachims M, Lloyd RE. 2002. Efficient cleavage of ribosome-associated poly(A)-binding protein by enterovirus $3 \mathrm{C}$ protease. J Virol 76: 2062-2074.

Kuyumcu-Martinez NM, Van Eden ME, Younan P, Lloyd RE. 2004b. Cleavage of poly(A)-binding protein by poliovirus $3 \mathrm{C}$ protease inhibits host cell translation: A novel mechanism for host translation shutoff. Mol Cell Biol 24: 1779-1790.

Lee SI, Steitz JA. 1990. Herpesvirus saimiri U RNAs are expressed and assembled into ribonucleoprotein particles in the absence of other viral genes. J Virol 64: 3905-3915.

Lee SI, Murthy SC, Trimble JJ, Desrosiers RC, Steitz JA. 1988. Four novel U RNAs are encoded by a herpesvirus. Cell 54: 599-607.

Lee YJ, Glaunsinger BA. 2009. Aberrant herpesvirus-induced polyadenylation correlates with cellular messenger RNA destruction. PLoS Biol 7: e1000107.

Lerner MR, Andrews NC, Miller G, Steitz JA. 1981a. Two small RNAs encoded by Epstein-Barr virus and complexed with protein are precipitated by antibodies from patients with systemic Lupus Erythematosus. Proc Natl Acad Sci 78: 805-809.

Lerner MR, Boyle JA, Hardin JA, Steitz JA. 1981b. Two novel classes of small ribonucleoproteins detected by antibodies associated with lupus erythematosus. Science 211: 400-402.

Lewis BP, Burge CB, Bartel DP. 2005. Conserved seed pairing, often flanked by adenosines, indicates that thousands of human genes are microRNA targets. Cell 120: 15-20.

Lin J, Cullen BR. 2007. Analysis of the interaction of primate retroviruses with the human RNA interference machinery. J Virol 81: $12218-12226$.

Lo AK, To KF, Lo KW, Lung RW, Hui JW, Liao G, Hayward SD. 2007. Modulation of LMP1 protein expression by EBV-encoded microRNAs. Proc Natl Acad Sci 104: 16164-16169.

Lu S, Cullen BR. 2004. Adenovirus VA1 noncoding RNA can inhibit small interfering RNA and microRNA biogenesis. J Virol 78: 12868-12876.

Luhrmann R. 2010. Spliceosome structure and function. Cold Spring Harb Perspect Biol 2: a003707.

Ma Y, Mathews MB. 1996. Structure, function, and evolution of adenovirus-associated RNA: A phylogenetic approach. J Virol 70: 5083-5099.

Maiese K, Chong ZZ, Shang YC, Hou J. 2008. Clever cancer strategies with FoxO transcription factors. Cell Cycle 7: 3829-3839.

Mathews MB, Shenk T. 1991. Adenovirus virus-associated RNA and translation control. J Virol 65: 5657-5662. 
Mongelard F, Bouvet P. 2007. Nucleolin: A multiFACeTed protein. Trends Cell Biol 17: 80-86.

Morgan R, Anderson A, Bernberg E, Kamboj S, Huang E, Lagasse G, Isaacs G, Parcells M, Meyers BC, Green PJ, Burnside J. 2008. Sequence conservation and differential expression of Marek's disease virus microRNAs. J Virol 82: 12213-12220.

Mrazek J, Kreutmayer SB, Grasser FA, Polacek N, Huttenhofer A. 2007. Subtractive hybridization identifies novel differentially expressed ncRNA species in EBV-infected human B cells. Nucleic Acids Res 35: e73.

Murphy E, Vanicek J, Robins H, Shenk T, Levine AJ. 2008. Suppression of immediate-early viral gene expression by herpesvirus-coded microRNAs: Implications for latency. Proc Natl Acad Sci 105: 5453-5458.

Murthy S, Kamine J, Desrosiers RC. 1986. Viral-encoded small RNAs in herpes virus saimiri induced tumors. EMBO J 5: 1625-1632.

Myer VE, Lee SI, Steitz JA. 1992. Viral small nuclear ribonucleoproteins bind a protein implicated in messenger RNA destabilization. Proc Natl Acad Sci 89: 1296-1300.

Nachmani D, Stern-Ginossar N, Sarid R, Mandelboim O. 2009. Diverse herpesvirus microRNAs target the stress-induced immune ligand MICB to escape recognition by natural killer cells. Cell Host Microbe 5: 376-385.

Nahvi A, Shoemaker CJ, Green R. 2009. An expanded seed sequence definition accounts for full regulation of the hid 3' UTR by bantam miRNA. RNA 15: 814-822.

Nanbo A, Inoue K, Adachi-Takasawa K, Takada K. 2002. Epstein-Barr virus RNA confers resistance to interferon- $\alpha$-induced apoptosis in Burkitt's lymphoma. EMBO J 21: 954-965.

Omoto S, Fujii YR. 2006. Cloning and detection of HIV-1-encoded microRNA. Methods Mol Biol 342: 255-265.

Ouellet DL, Plante I, Landry P, Barat C, Janelle ME, Flamand L, Tremblay MJ, Provost P. 2008. Identification of functional microRNAs released through asymmetrical processing of HIV-1 TAR element. Nucleic Acids Res 36: 2353-2365.

Pawlicki JM, Steitz JA. 2008. Primary microRNA transcript retention at sites of transcription leads to enhanced microRNA production. $J$ Cell Biol 182: 61-76.

Peng W, Vitvitskaia O, Carpenter D, Wechsler SL, Jones C. 2008. Identification of two small RNAs within the first $1.5-\mathrm{kb}$ of the herpes simplex virus type 1-encoded latency-associated transcript. J Neurovirol 14: $41-52$.

Pfeffer S, Sewer A, Lagos-Quintana M, Sheridan R, Sander C, Grasser FA, van Dyk LF, Ho CK, Shuman S, Chien M, et al. 2005. Identification of microRNAs of the herpesvirus family. Nat Methods 2: 269-276.

Pfeffer S, Zavolan M, Grasser FA, Chien M, Russo JJ, Ju J, John B, Enright AJ, Marks D, Sander C, et al. 2004. Identification of virus-encoded microRNAs. Science 304: 734-736.

Pijlman GP, Funk A, Kondratieva N, Leung J, Torres S, van der Aa L, Liu WJ, Palmenberg AC, Shi PY, Hall RA, et al. 2008. A highly structured, nuclease-resistant, noncoding RNA produced by flaviviruses is required for pathogenicity. Cell Host Microbe 4: 579-591.

Purzycka KJ, Adamiak RW. 2008. The HIV-2 TAR RNA domain as a potential source of viral-encoded miRNA. A reconnaissance study. Nucleic Acids Symp Ser (Oxf) 511-512.

Reeves MB, Davies AA, McSharry BP, Wilkinson GW, Sinclair JH. 2007. Complex I binding by a virally encoded RNA regulates mitochondriainduced cell death. Science 316: 1345-1348.

Reich PR, Forget BG, Weissman SM. 1966. RNA of low molecular weight in KB cells infected with adenovirus type 2. J Mol Biol 17: 428-439.

Revello MG, Gerna G. 2002. Diagnosis and management of human cytomegalovirus infection in the mother, fetus, and newborn infant. Clin Microbiol Rev 15: 680-715.

Riley KJ, Rabinowitz GS, Steitz JA. 2010. Comprehensive analysis of rhesus lymphocryptovirus microRNA expression. J Virol [AOP].

Ruf IK, Rhyne PW, Yang C, Cleveland JL, Sample JT. 2000. Epstein-Barr virus small RNAs potentiate tumorigenicity of Burkitt lymphoma cells independently of an effect on apoptosis. J Virol 74: 10223-10228.
Ruf IK, Lackey KA, Warudkar S, Sample JT. 2005. Protection from interferon-induced apoptosis by Epstein-Barr virus small RNAs is not mediated by inhibition of PKR. J Virol 79: 14562-14569.

Samols MA, Hu J, Skalsky RL, Renne R. 2005. Cloning and identification of a microRNA cluster within the latency-associated region of Kaposi's sarcoma-associated herpesvirus. J Virol 79: 9301-9305.

Samols MA, Skalsky RL, Maldonado AM, Riva A, Lopez MC, Baker HV, Renne R. 2007. Identification of cellular genes targeted by KSHV-encoded microRNAs. PLoS Pathog 3: e65.

Sano M, Kato Y, Taira K. 2006. Sequence-specific interference by small RNAs derived from adenovirus VAI RNA. FEBS Lett 580: $1553-1564$.

Schafer A, Cai X, Bilello JP, Desrosiers RC, Cullen BR. 2007. Cloning and analysis of microRNAs encoded by the primate $\gamma$-herpesvirus rhesus monkey rhadinovirus. Virology 364: 21-27.

Scott MS, Avolio F, Ono M, Lamond AI, Barton GJ. 2009. Human miRNA precursors with box H/ACA snoRNA features. PLoS Comput Biol 5: e1000507.

Seo GJ, Chen CJ, Sullivan CS. 2009. Merkel cell polyomavirus encodes a microRNA with the ability to autoregulate viral gene expression. Virology 383: 183-187.

Seo GJ, Fink LH, O'Hara B, Atwood WJ, Sullivan CS. 2008. Evolutionarily conserved function of a viral microRNA. J Virol 82: 9823-9828.

Sharp PA. 2010. Gene regulation by RNA. Cold Spring Harb Perspect Biol 2: a003715.

Sharp TV, Schwemmle M, Jeffrey I, Laing K, Mellor H, Proud CG, Hilse K, Clemens MJ. 1993. Comparative analysis of the regulation of the interferon-inducible protein kinase PKR by Epstein- Barr virus RNAs EBER-1 and EBER-2 and adenovirus VA1 RNA. Nucleic Acids Res 21: 4483-4490.

Shen W, Sa e Silva M, Jaber T, Vitvitskaia O, Li S, Henderson G, Jones C. 2009. Two small RNAs encoded within the first 1.5 kilobases of the herpes simplex virus type 1 latency-associated transcript can inhibit productive infection and cooperate to inhibit apoptosis. J Virol 83: 9131-9139.

Shimizu N, Tanabe-Tochikura A, Kuroiwa Y, Takada K. 1994. Isolation of Epstein-Barr virus (EBV)-negative cell clones from the EBV-positive Burkitt's lymphoma (BL) line Akata: Malignant phenotypes of BL cells are dependent on EBV. J Virol 68: 6069-6073.

Skalsky RL, Samols MA, Plaisance KB, Boss IW, Riva A, Lopez MC, Baker HV, Renne R. 2007. Kaposi's sarcoma-associated herpesvirus encodes an ortholog of miR-155. J Virol 81: 12836-12845.

Smith CA, Bates P, Rivera-Gonzalez R, Gu B, DeLuca NA. 1993. ICP4, the major transcriptional regulatory protein of herpes simplex virus type 1 , forms a tripartite complex with TATA-binding protein and TFIIB. J Virol 67: 4676-4687.

Soulier J, Grollet L, Oksenhendler E, Cacoub P, Cazals-Hatem D, Babinet P, d'Agay MF, Clauvel JP, Raphael M, Degos L, et al. 1995. Kaposi's sarcoma-associated herpesvirus-like DNA sequences in multicentric Castleman's disease. Blood 86: 1276-1280.

Spector DH. 1996. Activation and regulation of human cytomegalovirus early genes. Intervirology 39: 361-377.

Stevens JG, Wagner EK, Devi-Rao GB, Cook ML, Feldman LT. 1987. RNA complementary to a herpesvirus $\alpha$ gene mRNA is prominent in latently infected neurons. Science 235: 1056-1059.

Sullivan CS, Grundhoff AT, Tevethia S, Pipas JM, Ganem D. 2005. SV40-encoded microRNAs regulate viral gene expression and reduce susceptibility to cytotoxic T cells. Nature 435: 682-686.

Sullivan CS, Sung CK, Pack CD, Grundhoff A, Lukacher AE, Benjamin TL, Ganem D. 2009. Murine Polyomavirus encodes a microRNA that cleaves early RNA transcripts but is not essential for experimental infection. Virology 387: 157-167.

Sun R, Lin SF, Gradoville L, Miller G. 1996. Polyadenylylated nuclear RNA encoded by Kaposi sarcoma-associated herpesvirus. Proc Natl Acad Sci 93: 11883-11888. 
Sun R, Lin SF, Gradoville L, Yuan Y, Zhu F, Miller G. 1998. Aviral gene that activates lytic cycle expression of Kaposi's sarcoma-associated herpesvirus. Proc Natl Acad Sci 95: 10866-10871.

Swaminathan S, Tomkinson B, Kieff E. 1991. Recombinant Epstein-Barr virus with small RNA (EBER) genes deleted transforms lymphocytes and replicates in vitro. Proc Natl Acad Sci 88: 1546-1550.

Swaminathan S, Huneycutt BS, Reiss CS, Kieff E. 1992. Epstein-Barr virus-encoded small RNAs (EBERs) do not modulate interferon effects in infected lymphocytes. J Virol 66: 5133-5136.

Taft RJ, Glazov EA, Lassmann T, Hayashizaki Y, Carninci P, Mattick JS. 2009. Small RNAs derived from snoRNAs. RNA 15: 1233-1240.

Takizawa T, Tatematsu C, Watanabe M, Yoshida M, Nakajima K. 2000. Three leucine-rich sequences and the N-terminal region of doublestranded RNA-activated protein kinase (PKR) are responsible for its cytoplasmic localization. J Biochem 128: 471-476.

Tang S, Patel A, Krause PR. 2009. Novel less-abundant viral microRNAs encoded by herpes simplex virus 2 latency-associated transcript and their roles in regulating ICP34.5 and ICP0 mRNAs. J Virol 83: $1433-1442$.

Tang S, Bertke AS, Patel A, Wang K, Cohen JI, Krause PR. 2008. An acutely and latently expressed herpes simplex virus 2 viral microRNA inhibits expression of ICP34.5, a viral neurovirulence factor. Proc Natl Acad Sci 105: 10931-10936.

Thimmappaya B, Weinberger C, Schneider RJ, Shenk T. 1982. Adenovirus VAI RNA is required for efficient translation of viral mRNAs at late times after infection. Cell 31: 543-551.

Toczyski DP, Matera AG, Ward DC, Steitz JA. 1994. The Epstein-Barr virus (EBV) small RNA EBER1 binds and relocalizes ribosomal protein L22 in EBV-infected human B lymphocytes. Proc Natl Acad Sci 91: $3463-3467$.

Umbach JL, Cullen BR. 2009. The role of RNAi and microRNAs in animal virus replication and antiviral immunity. Genes Dev 23: $1151-1164$.

Umbach JL, Kramer MF, Jurak I, Karnowski HW, Coen DM, Cullen BR. 2008. MicroRNAs expressed by herpes simplex virus 1 during latent infection regulate viral mRNAs. Nature 454: 780-783.

Vasudevan S, Tong Y, Steitz JA. 2007. Switching from repression to activation: microRNAs can up-regulate translation. Science 318: 1931-1934.

Wahid AM, Coventry VK, Conn GL. 2008. Systematic deletion of the adenovirus-associated $\mathrm{RNA}_{\mathrm{I}}$ terminal stem reveals a surprisingly active RNA inhibitor of double-stranded RNA-activated protein kinase. J Biol Chem 283: 17485-17493.

Waidner LA, Morgan RW, Anderson AS, Bernberg EL, Kamboj S, Garcia M, Riblet SM, Ouyang M, Isaacs GK, Markis M, et al. 2009. MicroRNAs of Gallid and Meleagrid herpesviruses show generally conserved genomic locations and are virus-specific. Virology 388: 128-136.

Walz N, Christalla T, Tessmer U, Grundhoff A. 2010. A global analysis of evolutionary conservation among known and predicted $\gamma$ herpesvirus miRNAs. J Virol 84: 716-728.

Wang HW, Sharp TV, Koumi A, Koentges G, Boshoff C. 2002. Characterization of an anti-apoptotic glycoprotein encoded by Kaposi's sarcoma-associated herpesvirus which resembles a spliced variant of human survivin. EMBO J 21: 2602-2615.

Wassarman DA, Lee SI, Steitz JA. 1989. Nucleotide sequence of HSUR 5 RNA from herpesvirus saimiri. Nucleic Acids Res 17: 1258.

Weinberg MS, Morris KV. 2006. Are viral-encoded microRNAs mediating latent HIV-1 infection? DNA Cell Biol 25: 223-231.

Wolin SL, Cedervall T. 2002. The La protein. Annu Rev Biochem 71: 375-403.

Wu Y, Maruo S, Yajima M, Kanda T, Takada K. 2007. Epstein-Barr virus (EBV)-encoded RNA 2 (EBER2) but not EBER1 plays a critical role in EBV-induced B-cell growth transformation. J Virol 81: 1123611245.

Wu Z, Zhu Y, Bisaro DM, Parris DS. 2009. Herpes simplex virus type 1 suppresses RNA-induced gene silencing in mammalian cells. J Virol 83: $6652-6663$.

Xing L, Kieff E. 2007. Epstein-Barr Virus BHRF1 micro and stable RNAs in Latency III and after induction of replication. J Virol 18: 9967-9975.

Xu H, Yao Y, Zhao Y, Smith LP, Baigent SJ, Nair V. 2008. Analysis of the expression profiles of Marek's disease virus-encoded microRNAs by real-time quantitative PCR. J Virol Methods 149: 201-208.

Xu N, Segerman B, Zhou X, Akusjärvi G. 2007. Adenovirus virus-associated RNAII-derived small RNAs are efficiently incorporated into the RNA-induced silencing complex and associate with polyribosomes. J Virol 81: 10540-10549.

Yajima M, Kanda T, Takada K. 2005. Critical role of Epstein-Barr Virus (EBV)-encoded RNA in efficient EBV-induced B-lymphocyte growth transformation. J Virol 79: 4298-4307.

Yang L, Aozasa K, Oshimi K, Takada K. 2004. Epstein-Barr virus (EBV)-encoded RNA promotes growth of EBV-infected T cells through interleukin-9 induction. Cancer Res 64: 5332-5337.

Yao Y, Zhao Y, Smith LP, Watson M, Nair V. 2009. Novel microRNAs (miRNAs) encoded by herpesvirus of Turkeys: Evidence of miRNA evolution by duplication. J Virol 83: 6969-6973.

Yao Y, Zhao Y, Xu H, Smith LP, Lawrie CH, Sewer A, Zavolan M, Nair V. 2007. Marek's disease virus type 2 (MDV-2)-encoded microRNAs show no sequence conservation with those encoded by MDV-1.J Virol 81: 7164-7170.

Yao Y, Zhao Y, Xu H, Smith LP, Lawrie CH, Watson M, Nair V. 2008. MicroRNA profile of Marek's disease virus-transformed T-cell line MSB-1: Predominance of virus-encoded microRNAs. J Virol 82: 4007-4015.

Zhong W, Ganem D. 1997. Characterization of ribonucleoprotein complexes containing an abundant polyadenylated nuclear RNA encoded by Kaposi's sarcoma-associated herpesvirus (human herpesvirus 8). J Virol 71: 1207-1212.

Zhong W, Wang H, Herndier B, Ganem D. 1996. Restricted expression of Kaposi sarcoma-associated herpesvirus (human herpesvirus 8) genes in Kaposi sarcoma. Proc Natl Acad Sci 93: 6641-6646.

Zhu JY, Pfuhl T, Motsch N, Barth S, Nicholls J, Grasser F, Meister G. 2009. Identification of novel Epstein-Barr Virus miRNA genes from nasopharyngeal carcinomas. J Virol 83: 3333-3341. 


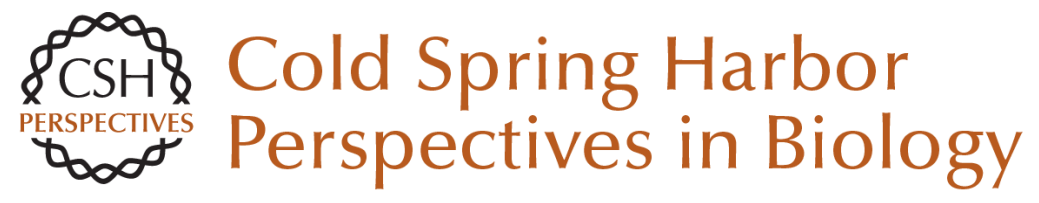

\section{Noncoding RNPs of Viral Origin}

Joan Steitz, Sumit Borah, Demian Cazalla, Victor Fok, Robin Lytle, Rachel Mitton-Fry, Kasandra Riley and Tasleem Samji

Cold Spring Harb Perspect Biol 2011; doi: 10.1101/cshperspect.a005165 originally published online August 18, 2010

\section{Subject Collection RNA Worlds}

Alternate RNA Structures

Marie Teng-Pei Wu and Victoria D'Souza

Approaches for Understanding the Mechanisms of Long Noncoding RNA Regulation of Gene Expression Patrick McDonel and Mitchell Guttman

Principles and Practices of Hybridization Capture Experiments to Study Long Noncoding RNAs That Act on Chromatin Matthew D. Simon and Martin Machyna

Linking RNA Sequence, Structure, and Function on Massively Parallel High-Throughput Sequencers Sarah K. Denny and William J. Greenleaf

Extensions, Extra Factors, and Extreme Complexity: Ribosomal Structures Provide Insights into Eukaryotic Translation Melanie Weisser and Nenad Ban

Nascent RNA and the Coordination of Splicing with Transcription

Karla M. Neugebauer
Structural Biology of Telomerase

Yaqiang Wang, Lukas Susac and Juli Feigon

Structural Insights into Nuclear pre-mRNA

Splicing in Higher Eukaryotes

Berthold Kastner, Cindy L. Will, Holger Stark, et al.

What Are 3' UTRs Doing?

Christine Mayr

Single-Molecule Analysis of Reverse

Transcriptase Enzymes

Linnea I. Jansson and Michael D. Stone

CRISPR Tools for Systematic Studies of RNA

Regulation

Jesse Engreitz, Omar Abudayyeh, Jonathan Gootenberg, et al.

Relating Structure and Dynamics in RNA Biology Kevin P. Larsen, Junhong Choi, Arjun Prabhakar, et al.

For additional articles in this collection, see http://cshperspectives.cshlp.org/cgi/collection/

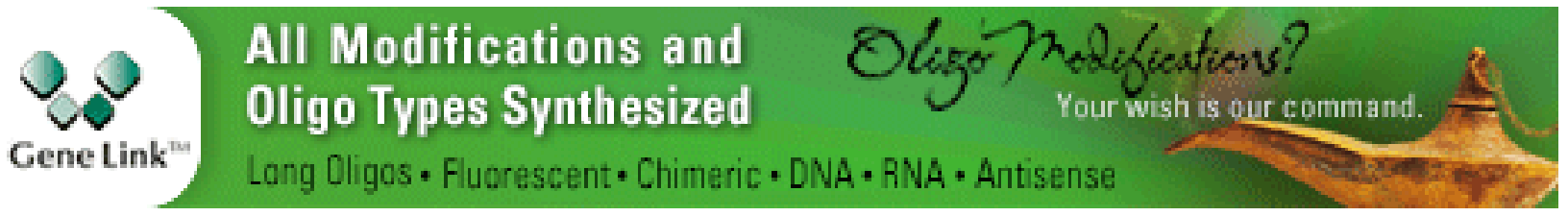

Copyright @ 2011 Cold Spring Harbor Laboratory Press; all rights reserved 
Combining Mass Spectrometry (MS) and Nuclear Magnetic Resonance (NMR) Spectroscopy for Integrative Structural Biology of Protein-RNA Complexes

Alexander Leitner, Georg Dorn and Frédéric H.-T. Allain

Discovering and Mapping the Modified Nucleotides That Comprise the Epitranscriptome of mRNA

Bastian Linder and Samie R. Jaffrey
Beyond DNA and RNA: The Expanding Toolbox of Synthetic Genetics

Alexander I. Taylor, Gillian Houlihan and Philipp Holliger

\section{Structural Basis of Nuclear pre-mRNA Splicing:} Lessons from Yeast

Clemens Plaschka, Andrew J. Newman and Kiyoshi Nagai

For additional articles in this collection, see http://cshperspectives.cshlp.org/cgi/collection/

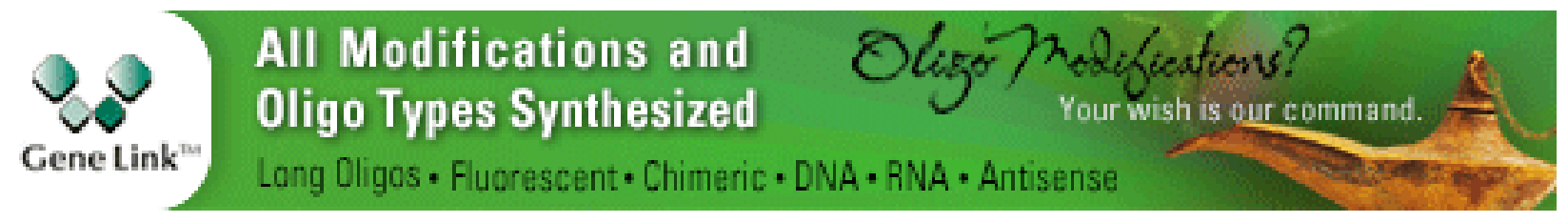

Copyright @ 2011 Cold Spring Harbor Laboratory Press; all rights reserved 